chemical cardioplegia and storage in isolated blood-perfused pig hearts. Thorac Cardiovasc Surg 1993;41:93-100.

24. Renstrom B, Nellis SH, Leidtke AJ. Metabolic oxidation of pyruvate and lactate during early myocardial reperfusion. Circ Res 1990;66:282-8.

25. Dingelborg LM, Kinne RKH, Greishaber MK. Transport and metabolism of L-glutamate during oxygenation, anoxia, and reoxygenation of rat cardiac myocytes. Am J Physiol 1996;270: H1825-32.

26. Taegtmeyer H. Energy metabolism in the heart: from basic concepts to clinical applications. Curr Probl Cardiol 1994;19: 74-7.

27. Taegtmeyer H, Goodwin GW, Doenst T, Frazier OH. Substrate metabolism as a determinant for postischemic functional recovery of the heart. Am J Cardiol 1997;80:3A-10A.

28. Camici P, Ferrannini E, Opie LH. Myocardial metabolism in ischemic heart disease: basic principles and application to imaging by positron emission tomography. Prog Cardiovasc Dis 1989; 32:217-38.

\title{
Bound volumes available to subscribers
}

Bound volumes of The Journal of Thoracic and Cardiovascular Surgery are available to subscribers (only) for the 2000 issues from the Publisher, at a cost of $\$ 134.00$ for domestic, $\$ 165.85$ for Canadian, and $\$ 155.00$ for international subscribers for Vol 119 (January-June) and Vol 120 (July-December). Shipping charges are included. Each bound volume contains a subject and author index and all advertising is removed. Copies are shipped within 60 days after publication of the last issue of the volume. The binding is durable buckram with the Journal name, volume number, and year stamped in gold on the spine. Payment must accompany all orders. Contact Mosby, Inc, Subscription Services, 11830 Westline Industrial Drive, St Louis, MO 63146-3318, USA; phone 800-453-4351 or 314-453-4351.

Subscriptions must be in force to qualify. Bound volumes are not available in place of a regular Journal subscription. 